\title{
UNPOPULAR SPECIES AND THEIR INCREASED USE ${ }^{1}$
}

\author{
BY G. D. MORRISON ${ }^{2}$
}

\begin{abstract}
This paper discusses the history of developments of the Hawkesbury Pulp Mill which led to utilization of mixed hardwoods. It includes a list of species utilized at Hawkesbury and the approximate percentages of each.

Problems associated with the use of such a wide variety of species are discussed together with the benefits of wider utilization which accrue to: (a) individual woodlot owners; (b) community as a whole; (c) the Company. The new trend in woodlot management since 1951 is reviewed and the measures taken by Grenville Woods Division to promote and accelerate good management practices on prviately owned woodlands were outlined.

It is very gratifying to see wider utilization coming in for so much attention at meetings such as this. Our experience at Grenville and Hawkesbury has shown that the benefits from wider utilization are very real to the individual woodlot owners, to our Company, and to the community as a whole.

But before going too deeply into this aspect of wider utilization, I would like to tell you something of the developments which have taken place in our area in the last few years.

Some of you are no doubt familiar with our Hawkesbury Pulp Mill and how, up to approximately 1950 , it was entirely dependent on spruce and balsam as its source of wood fibre. Local supplies had never been able to support this mill entirely and, in more recent years, it was found necessary to reach farther and farther afield to satisfy its needs. These measures, as you can well realize, were reffected in the cost of our product and increasing difficulty was being experienced in maintaining our position in the market.

This situation, developing as it did over a period of years, certainly did not go undetected and measures had been under way for some time to solve this problem before it became a crisis. These remedial measures took the form of research at our Industrial Cellulose Research Laboratory in Hawkesbury to devise ways and means of adapting our process to make use of the mixed hardwoods which nature grows in considerable abundance in the area. This research was sufficiently advanced by 1951 to warrant large-scale purchases
\end{abstract} of mixed hardwoods.

Grenville Woods Division, directly across the Ottawa River from Hawkesbury, was given the responsibility of making these purchases, and since 1951 they have been in the region of 120 thousand cords per year.

Since this panel is discussing "Unpopular Species and Their Increased Use", I would like to read the list of species that are utilized at Hawkesburv;

\footnotetext{
${ }^{1}$ Paper presented at the $48 \mathrm{th}$ Annual Meeting of the C.I.F. held on Oct. 2-5, 1956 in Chicourimi, P.Q.

Grenville Woods Division, Canadian International Paper Company, Grenville, Quebec.
} 
I think you will agree that considerable progress has been made towards our goal. The list includes the following species of hardwoods: ash, oak, soft maple, hard maple, beech, ironwood, elm, white birch, yellow birch, and poplar. In the softwoods, in addition to spruce and balsam, the species of hemlock, tamarack and pine are acceptable-in all, a total of fifteen main species.

In actual deliveries to date for 1956, hard maple and beech account for $43 \%$, soft maple $16 \%$, elm $17 \%$, yellow birch $7 \%$, and poplar $6 \%$. In the softwoods hemlock accounts for $45 \%$ and spruce and balsam together for $19 \%$.

White and red pine, very recent additions to our list, were the result of continuing efforts to further broaden our utilization. Last week, as far as the Hawkesbury Mill was concerned, pine was an unpopular species. This week it makes up $10 \%$ of the softwood deliveries. Who is to say what other species will get the Cinderella treatment as time goes by?

Using such a wide variety of species, however, is not without its problems, and from time to time the midnight gong threatens to sound for certain species. A case in point is elm. Actual deliveries of this species in 1951 and subsequent years ran as high as $30 \%$, whereas forecasts had predicted that elm would be a minor species. The result of this was that any variation in the quality of the pulp cast considerable suspicion on elm, so much so, in fact, that deliveries of this species are restricted to $20 \%$. Tests just completed, however, have vindicated the elm and it is hoped that purchases of this species may soon be allowed to free-wheel again.

Once placed on our purchasing list, no species has ever had to be removed, and large-scale production has invariably supported the predictions of our researchers. This, I am sure you will agree, is a real tribute to the groundwork laid by the Industrial Cellulose Research personnel and the Hawkesbury Mill personnel.

In opening I mentioned the benefits which accrue to the individual woodlot owners, to the Company and to the community as a result of this new market for low grade hardwoods. It does not require too much imagination to visualize the dollar savings to a mill when it is able to utilize wood growing on its doorstep, nor to visualize the benefits to the community as a whole when one and a half million dollars per year is added to the income of its inhabitants. More important than dollar benefits, however, are the benefits, forestry-wise, which these three parties will realize in the years ahead.

To understand this it is necessary to understand something of the wood markets available in Argenteuil and surrounding counties prior to 1951. Sawmills, large and small, were numerous, and three veneer mills were within trucking distance. But all of these outlets demand quality sawlogs, and a farmer wishing to realize a return from his woodlot had no recourse but to high-grade it. The effects of generations of high-grading can now be seen in practically every woodlot.

Since 1951, however, woodlot owners have been able to reverse this trend and many are taking advantage of our market to put their woodlots in a more 
productive condition. Windfalls are being salvaged, deformed and defective trees have taken on value, thinnings are being made and waste has been eliminated from logging operations. At Grenville we feel we have a very great responsibility to do everything possible to promote these and other good forest management practices. To discharge this responsibility we have taken the following steps, which we think will go a long way towards assuring continuous woodlot production in our procurement area.

Step 1. Sign contracts directly with the woodlot owner. This provides an opportunity to talk forest management with the owner and to advise him on cutting practices.

Step 2. Assign a forester to extension work.

Step 3. Establish a demonstration forest at The Harrington Forest Farm where woodlot owners can see forest management at work.

Step 4. Take an active part in promoting the Canadian Tree Farm Movement. This work has resulted in three local sponsoring committees being organized and has resulted in 77 properties being certified as Tree Farms in our area.

Step 5. Provide films, slides and speakers for any and all occasions.

As far as utilization is concerned, only basswood, butternut, hickory, black cherry and cedar remain to be conquered, and these occur only in very limited quantities. Attention is now being focussed on wood in unpopular forms such as slabs and edgings.

To sum up, it is felt that wider species utilization has made forest management both practical and profitable in our Hawkesbury - Grenville area. 